\title{
Bioaccumulation of Heavy Metals in Fish (Hydrocynus forskahlii, Hyperopisus bebe occidentalis and Clarias gariepinus) Organs in Downstream Ogun Coastal Water, Nigeria
}

\author{
Babatunde A. Murtala ${ }^{1}$, Waidi O. Abdul $^{1}$ \& Adeolu A. Akinyemi ${ }^{1}$ \\ ${ }^{1}$ Department of Aquaculture and Fisheries Management, Federal University of Agriculture, Abeokuta, Nigeria \\ Correspondence: Waidi O. Abdul, Department of Aquaculture and Fisheries Management, Federal University of \\ Agriculture, PMB 2240, Abeokuta, Nigeria. Tel: 234-818-342-9107. E-mail: walaxxy@gmail.com
}

Received: June 27, 2012 Accepted: July 23, 2012 Online Published: October 12, 2012

doi:10.5539/jas.v4n11p51 URL: http://dx.doi.org/10.5539/jas.v4n11p51

\begin{abstract}
In this study accumulation of some heavy metals Cadmium (Cd), Chromium (Cr), Cobalt (Co), Nickel (Ni) and Lead $(\mathrm{Pb})$ in the operculum, gills, heart, kidney, muscle and vertebrae were determined in some fishes (Hydrocynus forskahlii, Hyperopisus bebe occidentalis and Clarias gariepinus) collected from fishermen around Ogun estuary. The accumulation of the metals in different organs showed significant differences $(\mathrm{P}<0.05)$ except lead accumulation. However, the bioaccumulation of the heavy metals was species-related as the accumulations of the heavy metals analysed in the sampled fishes were of the following trend: H. forskahlii $>$ H. bebe occidentalis $>C$. gariepinus and the pattern of distribution was $\mathrm{Ni}>\mathrm{Cr}>\mathrm{Co}>\mathrm{Cd}>\mathrm{Pb}$ for all the fish species. The levels of $\mathrm{Ni}$ and $\mathrm{Cr}$ in this study were higher than the maximum permissible limits (FAO, UNEP, FEPA and $\mathrm{WHO}$ ) for human consumption and that of $\mathrm{Cd}, \mathrm{Pb}$ and $\mathrm{Co}$ were still lower. Safe disposals of domestic sewage and industrial effluents as well as enforcement of laws enacted to protect our environment are therefore advocated.
\end{abstract}

Keywords: heavy metal, ogun estuary, Nigeria, bioaccumulation

\section{Introduction}

Fish accumulate toxic chemicals such as heavy metals directly from water and diet, and contaminant residues may ultimately reach concentrations hundreds or thousands of times above those measured in the water, sediment and food (Goodwin et al., 2003; Labonne et al., 2001; Osman et al., 2007). Heavy metals are normal constituents of marine environment that occur as a result of pollution, principally due to the discharge of untreated wastes into rivers by many industries. Bioaccumulation of heavy metals in tissues of marine organisms has been identified as an indirect measure of the abundance and availability of metals in the marine environment (Kucuksegin et al., 2006). For this reason, monitoring fish tissue contamination serves an important function as an early warning indicator of sediment contamination or related water quality problems (Mansour \& Sidky, 2002; Barak \& Mason, 1990) and enables us to take appropriate action to protect public health and the environment. Multiple factors including season, physical and chemical properties of water can play a significant role in metal accumulation in different fish tissues (Hayat et al., 2007; Romeo et al., 1999). Several studies (Ademoroti, 1996; Cusimano et al., 1986; Heath, 1987; Allen, 1995; Karthikeyan et al., 2007) have also indicated that fish are able to accumulate and retain heavy metals from their environment depending upon exposure concentration and duration as well as salinity, temperature, hardness and metabolism of the animals. Adeyeye et al. (1996) also showed that the concentration of metals was a function of fish species as it accumulates more in some fish species than others.

Fish have been the most popular choice as test organisms because they are presumably the best-understood organisms in the aquatic environment (Buikema et al., 1982) and also due to their importance to man as a protein source (Kime et al., 1996). Therefore, this research was to determine the levels of contamination and the bioaccumulation of $\mathrm{Cd}, \mathrm{Ni}, \mathrm{Cr}, \mathrm{Co}$ and $\mathrm{Pb}$ on some fish species that are of commercial importance (H. forskahlii, H. bebe occidentalis and C. gariepinus) in Ogun estuary. 


\section{Materials and Methods}

\subsection{Description of Site}

The fish were collected from commercial fishermen in downstream Ogun estuary situated in Iwopin, Ogun Waterside Local Government. Its geographical coordinates are $6^{\circ} 31^{\prime} 0^{\prime \prime}$ North, $4^{\circ} 10^{\prime} 0^{\prime \prime}$ East on the map of Ogun waterside LGA, Ogun State, Nigeria. It receives a number of important rivers draining their waters into it and it borders the forest belt, Omo biospere (Idowu \& Ayoola, 2008). This estuary is an extension of Lekki lagoon which receives water from Ogun River at coordinates $3^{\circ} 25^{\prime \prime} \mathrm{E}$ and $6^{\circ} 35^{\prime \prime} \mathrm{N}$ (Adebisi et al., 1981), and it is the only area in Ogun State with a coastline on the Bright of Benin (Olaoye et al., 2012).

\subsection{Sample Collection}

Nine adult fish samples, three each of $H$. forskahlii (mean weight: $314.2 \pm 2.74 \mathrm{~g}$ and mean length: $33.0 \pm$ $1.15 \mathrm{~cm}$ ), H. bebe occidentalis (mean weight: $463.8 \pm 3.76 \mathrm{~g}$ and mean length: $36.7 \pm 0.88 \mathrm{~cm}$ ) and C. gariepinus (mean weight: $805.0 \pm 47.68 \mathrm{~g}$ and mean length: $39.3 \pm 1.45 \mathrm{~cm}$ ) were procured from fishermen around the Iwopin, Ogun estuary. These fish species were put in sterile polythene bags and taken in icebox to the laboratory where they were washed with running tap water to remove dirt. Fish samples were identified taxonomically using standard reference sources (www.fishbase.org).

All the fish samples were then separately stored inside the deep freezer at about $-10^{\circ} \mathrm{C}$ and were allowed to thaw; Scales were removed and washed with running water before dissected with sterile scissors to remove gills, operculum, vertebrae, heart, muscles and kidney. These were transferred into sterile sample bottles, labelled and kept for digestion and analysis of heavy metals.

\subsection{Sample Preparations}

Prior to digestion samples were separately dried in a laboratory oven at $65^{\circ} \mathrm{C}$ for three days to obtain a constant dry weight of $0.5 \mathrm{~g}$ from each sample. The dried samples were each ground to powder, using laboratory ceramic mortar and pestle, and sieved with $2 \mathrm{~mm}$ sieve.

\subsection{Digestion of Sample}

The powdered samples were digested using the procedure described by Novozamsky et al. (1983) as follows:

$0.200 \mathrm{~g}$ of dry, powdered fish sample was weighed into a $50 \mathrm{ml}$ digestion tube and $2.5 \mathrm{ml}$ of Selenium/Sulfuric Acid mixture was added to each tube and to 5 blanks, used for standards. This was placed in an aluminium block on a hotplate, heat at approximately $200{ }^{\circ} \mathrm{C}$ until the sample fumes.

The tubes were then removed from the hotplates and allowed to cool for 10 minutes. $1 \mathrm{ml}$ of $30 \% \mathrm{H}_{2} \mathrm{O}_{2}$ was carefully added to the samples and standards. After the reaction subsided it was followed with additional $2 \mathrm{ml}$ $\mathrm{H}_{2} \mathrm{O}_{2}$.

Tubes were replaced on hotplates and a heavy $15 \mathrm{ml}$ glass vial was placed on top of each tube, and the tubes were heated up to $330^{\circ} \mathrm{C}$. This was left on the hot plates until the solutions were clear (usually 2 hours).

These samples were allowed to cool and $0 \mathrm{ml}, 0.2 \mathrm{ml}, 0.4 \mathrm{ml}, 0.6 \mathrm{ml}$ and $0.8 \mathrm{ml}$ of stock solutions for each of the heavy metals to be analysed were added to the 5 standard solutions. The samples and standards were then diluted to the $50 \mathrm{ml}$ mark.

\subsection{Determination of Heavy Metals}

Samples were then poured into auto-analyser cups and concentration of heavy metals (cadmium, cobalt, chromium, nickel and lead) in each was determined using Atomic Absorption Spectrophotometer (AAS). The values of the heavy metal concentrations in the tissues were calculated based on dry weights as this discounted the variability due to inner parts differences in the moisture content of organisms.

\subsection{Statistical Analysis}

Results are presented as means \pm SEM, where $\mathrm{n}$ equals the number of fish samples from which tissues were isolated. Results from all the specimens were compared using ANOVA and $\mathrm{P}<0.05$ was considered to indicate statistical significant difference. Means of significant differences were separated using Duncan's Multiple Range Test.

\section{Results and Discussion}

Cadmium (Cd), Chromium (Cr), Cobalt (Co), Nickel $(\mathrm{Ni})$ and Lead $(\mathrm{Pb})$ were analysed and the levels of the heavy metals concentration were measured in each of the fish samples' operculum, gills, kidney, heart, muscle and vertebrae using Atomic Absorption Spectrophotometer. The results of the analysis are presented in Table 1 
and further illustrated in Figures 1-3.

Table 1. Mean concentration (ppm) of heavy metals in the tissues of the fish species in Ogun estuary, Ogun State, Nigeria. Values are presented in means \pm S.E

\begin{tabular}{|c|c|c|c|c|c|c|}
\hline Fish & Organs & $\mathrm{Cd}$ & $\mathrm{Ni}$ & $\mathrm{Cr}$ & Co & $\mathrm{Pb}$ \\
\hline \multirow[t]{6}{*}{ H. forskahlii } & Operculum & $\begin{array}{c}0.41 \pm 0.08 \\
\mathrm{a}\end{array}$ & $2.74 \pm 1.40_{\mathrm{b}}$ & $0.37 \pm 0.20_{\mathrm{c}}$ & $\begin{array}{c}0.73 \pm 0.02 \\
\mathrm{~b}\end{array}$ & $\begin{array}{c}0.07 \pm 0.04 \\
\mathrm{a}\end{array}$ \\
\hline & Gills & $\begin{array}{c}0.39 \pm 0.08 \\
\text { a }\end{array}$ & $3.00 \pm 1.44_{\mathrm{b}}$ & $1.35 \pm 0.03_{\mathrm{b}}$ & $\begin{array}{c}0.48 \pm 0.20 \\
\mathrm{~b}\end{array}$ & $\begin{array}{c}0.25 \pm 0.20 \\
\mathrm{a}\end{array}$ \\
\hline & Kidney & $\begin{array}{c}0.00 \pm 0.00 \\
\mathrm{c}\end{array}$ & $6.33 \pm 0.73_{\mathrm{a}}$ & $5.64 \pm 1.85_{\mathrm{a}}$ & $\begin{array}{c}1.17 \pm 0.22 \\
\mathrm{a}\end{array}$ & $\begin{array}{c}0.03 \pm 0.00 \\
\mathrm{a}\end{array}$ \\
\hline & Heart & $\begin{array}{c}0.15 \pm 0.08 \\
\mathrm{~b}\end{array}$ & $2.45 \pm 0.05_{\mathrm{c}}$ & $2.47 \pm 0.60_{\mathrm{a}}$ & $\begin{array}{c}0.00 \pm 0.00 \\
\text { c }\end{array}$ & $\begin{array}{c}0.04 \pm 0.02 \\
\mathrm{a}\end{array}$ \\
\hline & Muscle & $\begin{array}{c}0.26 \pm 0.00 \\
\mathrm{~b}\end{array}$ & $2.56 \pm 1.44_{\mathrm{a}}$ & $1.36 \pm 0.02_{\mathrm{a}}$ & $\begin{array}{c}0.43 \pm 0.23 \\
\mathrm{~b}\end{array}$ & $\begin{array}{c}0.05 \pm 0.03 \\
\mathrm{a}\end{array}$ \\
\hline & Vertebrae & $\begin{array}{c}0.45 \pm 0.23 \\
\mathrm{a}\end{array}$ & $0.00 \pm 0.00_{\mathrm{d}}$ & $1.33 \pm 0.05_{\mathrm{b}}$ & $\begin{array}{c}0.42 \pm 0.22 \\
\mathrm{~b}\end{array}$ & $\begin{array}{c}0.02 \pm 0.01 \\
\mathrm{a}\end{array}$ \\
\hline \multirow[t]{6}{*}{ H. bebe occidentalis } & Operculum & $\begin{array}{c}0.32 \pm 0.16 \\
\mathrm{a}\end{array}$ & $0.02 \pm 0.01_{\mathrm{c}}$ & $0.79 \pm 0.41_{\mathrm{c}}$ & $\begin{array}{c}1.66 \pm 0.46 \\
\mathrm{a}\end{array}$ & $\begin{array}{c}0.04 \pm 0.02 \\
\text { b }\end{array}$ \\
\hline & Gills & $\begin{array}{c}0.25 \pm 0.01 \\
\mathrm{a}\end{array}$ & $5.00 \pm 0.00_{\mathrm{a}}$ & $1.95 \pm 0.68_{\mathrm{b}}$ & $\begin{array}{c}1.23 \pm 0.67 \\
\mathrm{a}\end{array}$ & $\begin{array}{c}0.03 \pm 0.01 \\
\mathrm{a}\end{array}$ \\
\hline & Kidney & $\begin{array}{c}0.00 \pm 0.00 \\
\mathrm{~b}\end{array}$ & $3.66 \pm 0.84_{b}$ & $4.95 \pm 2.15_{\mathrm{a}}$ & $\begin{array}{c}0.00 \pm 0.00 \\
\mathrm{c}\end{array}$ & $\begin{array}{c}0.02 \pm 0.01 \\
\mathrm{a}\end{array}$ \\
\hline & Heart & $\begin{array}{c}0.15 \pm 0.08 \\
\mathrm{~b}\end{array}$ & $3.72 \pm 0.75_{\mathrm{b}}$ & $0.68 \pm 0.40_{\mathrm{c}}$ & $\begin{array}{c}2.32 \pm 0.89 \\
\mathrm{a}\end{array}$ & $\begin{array}{c}0.02 \pm 0.01 \\
\mathrm{a}\end{array}$ \\
\hline & Muscle & $\begin{array}{c}0.13 \pm 0.08 \\
\mathrm{~b}\end{array}$ & $0.00 \pm 0.00_{\mathrm{d}}$ & $1.30 \pm 0.08_{\mathrm{b}}$ & $\begin{array}{c}0.37 \pm 0.22 \\
\text { b }\end{array}$ & $\begin{array}{c}0.01 \pm 0.00 \\
\mathrm{a}\end{array}$ \\
\hline & Vertebrae & $\begin{array}{c}0.13 \pm 0.08 \\
\mathrm{~b}\end{array}$ & $0.02 \pm 0.01_{\mathrm{c}}$ & $0.98 \pm 0.17_{\mathrm{c}}$ & $\begin{array}{c}1.12 \pm 0.24 \\
\mathrm{a}\end{array}$ & $\begin{array}{c}0.01 \pm 0.00 \\
\mathrm{a}\end{array}$ \\
\hline \multirow[t]{6}{*}{ C. gariepinus } & Operculum & $\begin{array}{c}0.13 \pm 0.08 \\
\text { c }\end{array}$ & $2.67 \pm 0.17 \mathrm{a}$ & $1.76 \pm 0.58_{\mathrm{b}}$ & $\begin{array}{c}0.46 \pm 0.06 \\
\mathrm{~b}\end{array}$ & $\begin{array}{c}0.09 \pm 0.01 \\
\mathrm{a}\end{array}$ \\
\hline & Gills & $\begin{array}{c}0.29 \pm 0.16 \\
\mathrm{~b}\end{array}$ & $1.30 \pm 0.70_{\mathrm{c}}$ & $2.54 \pm 0.92_{\mathrm{a}}$ & $\begin{array}{c}0.06 \pm 0.03 \\
\mathrm{c}\end{array}$ & $\begin{array}{c}0.01 \pm 0.00 \\
\mathrm{a}\end{array}$ \\
\hline & Kidney & $\begin{array}{c}0.41 \pm 0.08 \\
\mathrm{a}\end{array}$ & $3.43 \pm 1.70_{\mathrm{a}}$ & $2.61 \pm 0.15_{\mathrm{a}}$ & $\begin{array}{c}0.46 \pm 0.23 \\
\mathrm{~b}\end{array}$ & $\begin{array}{c}0.03 \pm 0.01 \\
\mathrm{a}\end{array}$ \\
\hline & Heart & $\begin{array}{c}0.26 \pm 0.15 \\
\mathrm{~b}\end{array}$ & $\begin{array}{c}1.86 \pm 0.56_{b} \\
c\end{array}$ & $1.73 \pm 0.20_{\mathrm{b}}$ & $\begin{array}{c}0.55 \pm 0.28 \\
\mathrm{~b}\end{array}$ & $\begin{array}{c}0.01 \pm 0.00 \\
\mathrm{a}\end{array}$ \\
\hline & Muscle & $\begin{array}{c}0.00 \pm 0.00 \\
\mathrm{~d}\end{array}$ & $1.37 \pm 0.66_{\mathrm{c}}$ & $1.36 \pm 0.02_{\mathrm{c}}$ & $\begin{array}{c}0.00 \pm 0.00 \\
\mathrm{~d}\end{array}$ & $\begin{array}{c}0.03 \pm 0.00 \\
\mathrm{a}\end{array}$ \\
\hline & Vertebrae & $\begin{array}{c}0.28 \pm 0.15 \\
\mathrm{~b}\end{array}$ & $2.44 \pm 0.06_{b}$ & $1.70 \pm 0.60_{\mathrm{bc}}$ & $\begin{array}{c}1.16 \pm 0.20 \\
\mathrm{a} \\
\end{array}$ & $\begin{array}{c}0.02 \pm 0.00 \\
\mathrm{a} \\
\end{array}$ \\
\hline $\begin{array}{r}\text { WHO (1985)/ FEPA (2003 } \\
\text { fo }\end{array}$ & 3) Limit in fish & $2.0 \mathrm{ppm}$ & $\begin{array}{c}0.5-0.6 \mathrm{pp} \\
\mathrm{m}\end{array}$ & $\begin{array}{c}0.15-1.0 \mathrm{pp} \\
\mathrm{m}\end{array}$ & - & $2.0 \mathrm{ppm}$ \\
\hline
\end{tabular}

Means with the same letters within a column (bearing the same organ) are not significantly different at $\mathrm{p}<0.05$

Data on heavy metal concentration in the operculum, gill, heart, Kidney, vertebrae and muscle of $H$. forskahlii, $H$. bebe occidentalis, and $C$. gariepinus showed that heavy metals were accumulated in the different organs as follows: H. forskahlii; Operculum - $\mathrm{Co}>\mathrm{Cd}>\mathrm{Cr}>\mathrm{Ni}>\mathrm{Pb}$, Gills - $\mathrm{Ni}>\mathrm{Cr}>\mathrm{Co}>\mathrm{Cd}>\mathrm{Pb}$, Kidney $-\mathrm{Ni}>\mathrm{Cr}>$ $\mathrm{Co}>\mathrm{Pb}>\mathrm{Cd}$, Heart $-\mathrm{Cr}>\mathrm{Ni}>\mathrm{Cd}>\mathrm{Pb}>\mathrm{Co}$, Muscle $-\mathrm{Ni}>\mathrm{Cr}>\mathrm{Co}>\mathrm{Cd}>\mathrm{Pb}$, Vertebrae $-\mathrm{Cr}>\mathrm{Cd}>\mathrm{Co}>$ $\mathrm{Pb}>\mathrm{Ni}$ : H. bebe occidentalis; Operculum - $\mathrm{Co}>\mathrm{Cr}>\mathrm{Cd}>\mathrm{Pb}>\mathrm{Ni}$, Gills $-\mathrm{Ni}>\mathrm{Cr}>\mathrm{Co}>\mathrm{Cd}>\mathrm{Pb}$, Kidney $\mathrm{Cr}>\mathrm{Ni}>\mathrm{Pb}>\mathrm{Cd}=\mathrm{Co}$, Heart $-\mathrm{Ni}>\mathrm{Co}>\mathrm{Cr}>\mathrm{Cd}>\mathrm{Pb}$, Muscle $-\mathrm{Cr}>\mathrm{Co}>\mathrm{Cd}>\mathrm{Pb}>\mathrm{Ni}$, Vertebrae $-\mathrm{Co}>$ $\mathrm{Cr}>\mathrm{Cd}>\mathrm{Ni}>\mathrm{Pb}$ : C. gariepinus; Operculum - $\mathrm{Ni}>\mathrm{Cr}>\mathrm{Co}>\mathrm{Cd}>\mathrm{Pb}$, Gills $-\mathrm{Cr}>\mathrm{Ni}>\mathrm{Cd}>\mathrm{Co}>\mathrm{Pb}$, Kidney - $\mathrm{Ni}>\mathrm{Cr}>\mathrm{Co}>\mathrm{Cd}>\mathrm{Pb}$, Heart $-\mathrm{Ni}>\mathrm{Cr}>\mathrm{Co}>\mathrm{Cd}>\mathrm{Pb}$, Muscle $-\mathrm{Cr}>\mathrm{Co}>\mathrm{Ni}>\mathrm{Pb}>\mathrm{Cd}$, Vertebrae $-\mathrm{Ni}>\mathrm{Cr}>\mathrm{Co}>\mathrm{Cd}>\mathrm{Pb}$. 


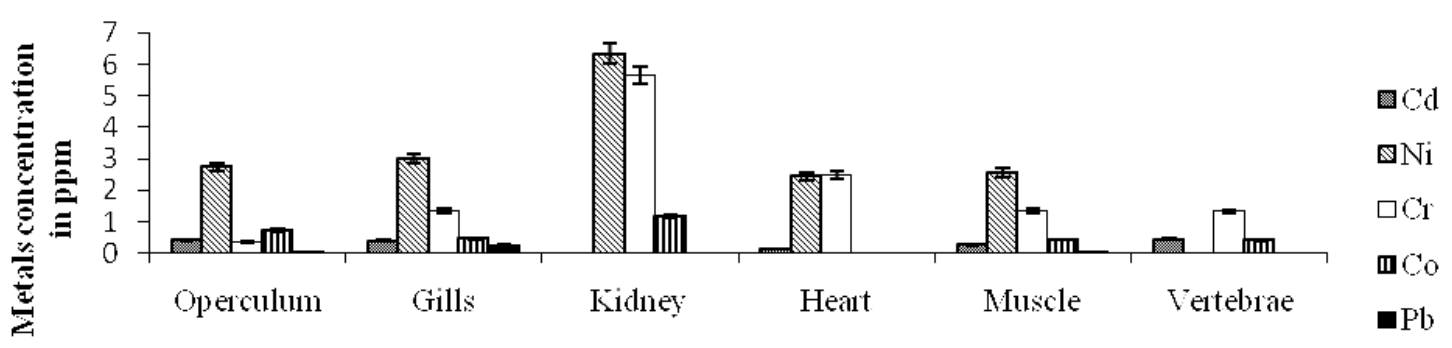

Hy.drochunsforskalthit

Figure 1. Distribution of cadmium (Cd), nickel (Ni), chromium (Cr), cobalt ( $\mathrm{Co}$ ) and lead $(\mathrm{Pb})$ in the operculum, gills, kidney, heart, muscle and vertebrae of Hydrocynus forskahlii from Ogun estuary. Values are means $\pm \mathrm{SE}$ of 3 fish

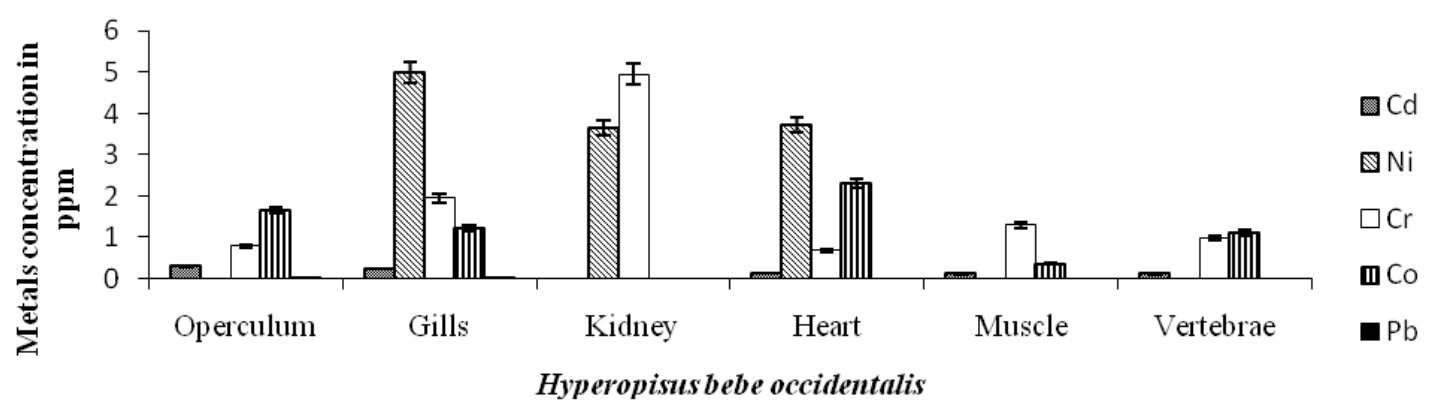

Figure 2. Distribution of cadmium(Cd), nickel(Ni), chromium $(\mathrm{Cr})$, cobalt $(\mathrm{Co})$ and lead $(\mathrm{Pb})$ in the operculum, gills, kidney, heart, muscle and vertebrae of $H$. bebe occidentalis from Ogun estuary. Values are means $\pm \mathrm{SE}$ of 3 fish

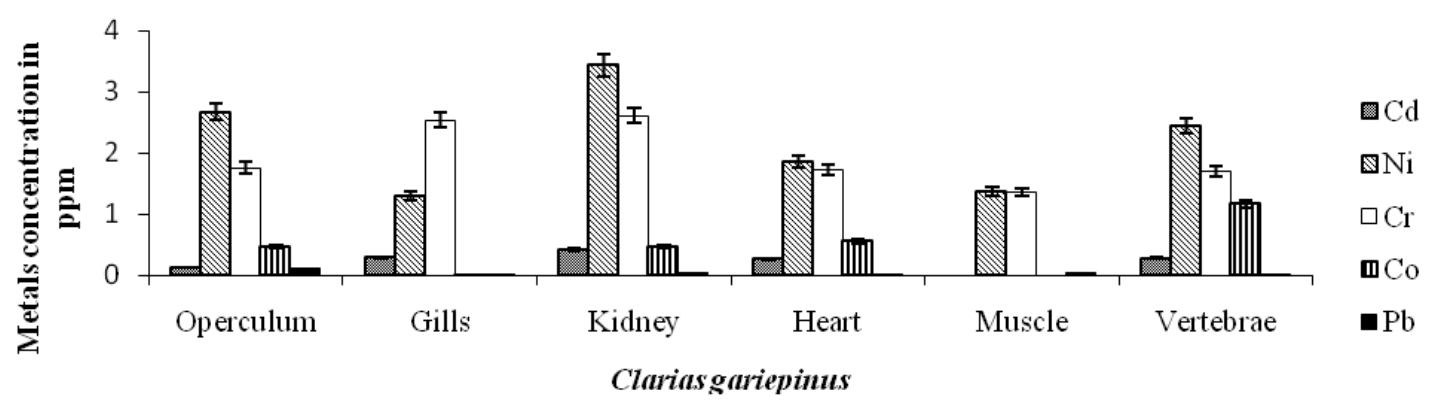

Figure 3. Distribution of cadmium(Cd), nickel(Ni), chromium(Cr), cobalt(Co) and lead( $\mathrm{Pb})$ in the operculum, gills, kidney, heart, muscle and vertebrae of $C$. gariepinus from Ogun estuary. Values are means $\pm \mathrm{SE}$ of 3 fish

The distribution of heavy metals in the various organs of the fishes sampled in the Ogun estuary is presented in Table 1 and further illustrated in Figures 1-3. The concentration of cadmium varied; in $H$. forskahlii from $0.00 \mathrm{ppm}$ in kidney to $0.45 \mathrm{ppm}$ in the vertebrae, in $H$. bebe occidentalis from $0.00 \mathrm{ppm}$ in the kidney to $0.32 \mathrm{ppm}$ in the operculum and in C. gariepinus from $0.00 \mathrm{ppm}$ in the muscle to $0.41 \mathrm{ppm}$ in the kidney. According to Gosselin et al. (1984), cadmium accumulates in liver and kidney, and more in the kidney than liver (McCracken, 1987; Venugopal \& Luckey, 1978). The cadmium concentration reported in the kidney and heart of C. gariepinus is in agreement with the studies by Ashraf (2005) who reported a concentration of $0.41 \mathrm{ppm}$ in the kidney of Epinephelus microdon fish from Arabian Gulf and Farombi et al. (2007) who reported a concentration of $0.69 \mathrm{ppm}$ in the kidney and $0.25 \mathrm{ppm}$ in the heart of C. gariepinus from Ogun River. Several studies have reported higher levels of $\mathrm{Cd}$ in different fish samples from some Nigerian rivers. These include Odoemelan (2005) who reported $1.50 \mathrm{ppm}$ and $1.23 \mathrm{ppm}$ in Alestes nurse and Synodontis nigritis respectively from Oguta Lake and Ishaq et al. (2011) reported $0.927 \mathrm{ppm}$ and $0.994 \mathrm{ppm}$ in C. gariepinus and T. zillii respectively from River Benue. 
Okoye (1991) reported concentration of 2ppm for cadmium and Oronsaye et al. (2010) reported cadmium of $0.79-0.98 \mathrm{ppm}$. The levels of $\mathrm{Cd}(0.00-0.45 \mathrm{ppm})$ recorded in fish samples were lower than the maximum recommended limits of 2.00ppm (WHO, 1985; FEPA, 2003) in fish food.

The concentration of nickel varied; in the $H$. forskahlii from $0.00 \mathrm{ppm}$ in the vertebrae to $6.33 \mathrm{ppm}$ in the kidney, in the $H$. bebe occidentalis from $0.00 \mathrm{ppm}$ in the muscle to $5.00 \mathrm{ppm}$ in the gills and in the $C$. gariepinus from $1.30 \mathrm{ppm}$ in the gills to $3.43 \mathrm{ppm}$ in the kidney. This is in agreement with the findings of Idodo-Umeh (2002) who reported $1.64-3.58 \mathrm{ppm}$ from fishes from Olomoro water bodies. However, lower level $(0.24$ and $0.36 \mathrm{ppm}$ in Mormyops deliciosus and Mormyrus macrophthalmus) has been reported by Oronsaye et al. (2010) from Ikpoba river dam. The result from the present study $(0.00-6.33 \mathrm{ppm})$ was higher compared with the maximum recommended limits of $0.5-0.6 \mathrm{ppm}$ (WHO, 1985; FEPA, 2003) in fish food.

The concentration of chromium varied; in $H$. forskahlii from $0.37 \mathrm{ppm}$ in the operculum to $5.64 \mathrm{ppm}$ in the kidney, in $H$. bebe occidentalis from $0.68 \mathrm{ppm}$ in the heart to $4.95 \mathrm{ppm}$ in the kidney and in C. gariepinus from $1.36 \mathrm{ppm}$ in the muscle to $2.67 \mathrm{ppm}$ in the operculum. Chromium level of $0.40-5.61 \mathrm{ppm}$ was reported from an investigation on Parachanna obscura from Ogba River in Benin City by Obasohan (2007) and 29.8 - 31.6ppm from T. zillii and 28.1 - 32.2ppm from C. gariepinus from River Benue (Ishaq et al., 2011). Also Nwani et al., (2010) reported 1.19ppm in Chyrsichthys nigrodigitatus from lotic freshwater ecosystem at Afikpo and Odoemelan (2005) reported 1.86ppm in A. nurse from Oguta Lake. The results in this investigation were lower than 29.8 - 31.6ppm in T. zillii and 28.1 - 32.2ppm in C. gariepinus from River Benue (Ishaq et al., 2011). The levels of $\mathrm{Cr}(0.37-5.64 \mathrm{ppm})$ recorded in fish samples were higher than the maximum recommended limits of 0.15 - 1.0ppm (WHO, 1985; FEPA, 2003; FAO, (1983) in fish food.

The concentration of cobalt varied; in $H$. forskahlii from $0.00 \mathrm{ppm}$ in the heart to $1.17 \mathrm{ppm}$ in the kidney, in $\mathrm{H}$. bebe occidentalis from $0.00 \mathrm{ppm}$ in the kidney to $2.32 \mathrm{ppm}$ in the heart, and in C. gariepinus from $0.00 \mathrm{ppm}$ in the muscle to $1.16 \mathrm{ppm}$ in the vertebrae. However, the level reported in this study was in agreement with the findings of Eralagere and Bhadravathi (2008) where 0.039 - 1.44ppm were reported in Oreochromis mossambicus from Jannapura Lake in India. The distribution of cobalt in H. forskahlii showed that the kidney has about $36 \%$ (Figure 1) which suggests that the route of exposure of the fish to cobalt could be through water (Coughtrey \& Thorne, 1983). This is different with other fish species suggesting that the route of uptake of the metal could be through food. Furthermore, the result showed that the bottom feeding fish (H. bebe occidentalis) has higher level of cobalt accumulation. This can be as a result of the higher exposure of bottom feeding fish due to the high cobalamine concentration in the sediments and feeding habits. Surface water fish in the study (H. forskahlii \& $C$. gariepinus) have higher level of $\mathrm{Cd}$ compared to the demersal fish species. This could be attributed to the fact that the bottom sediment concentration of cadmium is less available because of continuous release of electrons to the environment through microorganism respiration processes (Kersten \& Forstner, 1987), thus making the exposure to be higher for the pelagic species.

The concentration of lead varied; in $H$. forskahlii from $0.02 \mathrm{ppm}$ in the vertebrae to $0.25 \mathrm{ppm}$ in the gills, in $H$. bebe occidentalis from $0.01 \mathrm{ppm}$ in the muscle and vertebrae to $0.04 \mathrm{ppm}$ in the operculum and in C. gariepinus from $0.01 \mathrm{ppm}$ in the gills and heart to $0.10 \mathrm{ppm}$ in the operculum. This result was lower compared to the findings $0.395-0.62 \mathrm{ppm}$ of Doherty et al. (2010) and 9ppm Okoye (1991) of lead in some fishes from Lagos lagoon. Farombi et al. (2007) also reported $0.73-4.12 \mathrm{ppm}$ in C. gariepinus from Ogun River, Obasohan et al. (2006) reported $0.10-0.83 \mathrm{ppm}$ in some fishes from Ogba river and Oronsaye et al. (2010) also gave 3.53ppm and $2.67 \mathrm{ppm}$ in Mormyrops delicisus and Mormyrus macrophthalmus from Ikpoba river dam. The values obtained for lead in this study is in line with that of Daka et al. (2008) who obtained 0.01-0.06ppm in fish species from Azuabie creek in the Bonny estuary, Nigeria. Some results revealed high accumulation of heavy metals, for example, Doherty et al. (2010) reported $0.44 \mathrm{ppm}$ and $0.62 \mathrm{ppm}$ of lead in C. nigrodigitatus and T. guineensis respectively. The levels of $\mathrm{Pb}(0.01-0.25 \mathrm{ppm})$ recorded in fish samples under this investigation were lower than the maximum recommended limits of 2.0ppm (WHO, 1985; FEPA, 2003; FAO, 1983) in fish food.

The accumulation of the metals $(\mathrm{Cd}, \mathrm{Ni}, \mathrm{Cr}, \mathrm{Co}$ and $\mathrm{Pb})$ was higher in the gills than muscle of $H$. forskahlii and H. bebe occidentalis. This is in line with the previous studies of Nwani et al. (2010) and Edem et al. (2009). This accumulation was, however, significantly higher $(\mathrm{P}<0.05)$ only in $H$. bebe occidentalis. Gill tissues play an important role in interface with the environment in performing its functions in gas exchange, ion regulation, acid balance and waste excretion while muscle, on the other hand, is not an active tissue in bioaccumulation (Bajc et al., 2005; Filazi et al., 2003; Shukla et al., 2007).

It was noted from this study that accumulation of all the metals sampled in the kidney of $H$. forskahlii was not significantly higher $(\mathrm{P}>0.05)$ than that of $H$. bebe occidentalis and $C$. gariepinus. Also accumulation of these 
metals in the kidney of $H$. forskahlii was significantly higher $(\mathrm{P}<0.05)$ than muscle and vertebrae but not significantly higher in other organs. The kidney of $H$. bebe occidentalis had the highest accumulation of total metals. The concentrations were significantly higher $(\mathrm{P}<0.05)$ than those in operculum, muscle or vertebrae though not significantly higher than the accumulations in the gills and heart. C. gariepinus had the highest accumulation of the total metals in kidney followed by operculum, gills, heart, muscle and vertebrae but the difference was not significant $(\mathrm{P}>0.05)$. In addition, kidney played a major role in the accumulation of the heavy metals by $H$. forskahlii and $C$. gariepinus.

In the present study, it was observed that the total concentration of nickel in all the organs studied was significantly higher when compared with that of cadmium $(\mathrm{P}<0.05)$ but not significantly higher than that of chromium. Chromium was significantly higher than cobalt, and cobalt was significantly higher than lead in total heavy metals accumulation in all the fish species sampled under this investigation. It can be deduced from the above that accumulation of the heavy metals is more of species-related. In addition to this, it was noted that there was no relationship between the accumulation patterns of different metals in the different fishes. Thus, the differences noticed in the levels of accumulation in different organs of a fish can be attributed to the differences in their physiological roles toward maintaining homeostasis, feeding habits, regulatory ability and behaviour of each fish. This is in accordance with the findings of Cross et al. (1973). However, majorly muscle had the least concentration of the heavy metals compared with gills in the fish species sampled. This is in agreement with previous study by Ishaq et al. (2011) which showed that muscle is not an active organ in the accumulation of heavy metals. Gills, on the other hand, has been reported as metabolically active site and can accumulate heavy metals in higher level. This is evidenced by the position that the gills occupied in the accumulation pattern for the heavy metals. The presence of metal binding protein, metalotheonin, has favoured the accumulation of heavy metals in the kidney as it was shown to have the higher level of some of the heavy metals analysed in this investigation in the fish species. Low concentration of cadmium has been reported in previous studies (Olaifa et al., 2004), as observed in H. bebe occidentalis and H. forskahlii, and this has been suggested to be due to low tendency of cadmium towards the available active sites ( $\mathrm{N}$ and/or $\mathrm{O}$ donor atoms) in kidney tissues (Kappus, 1987).

In general, accumulation of the heavy metals (total mean) analysed in the sampled fishes was of the following trend: H. forskahlii $>\mathrm{H}$. bebe occidentalis $>$ C. gariepinus and the pattern of distribution was $\mathrm{Ni}>\mathrm{Cr}>\mathrm{Co}>$ $\mathrm{Cd}>\mathrm{Pb}$ for all the fish species. This showed that the accumulation of the heavy metals was species-related as $H$. forskahlii is predatory and carnivorous which might have favoured its higher tendency for metal bioaccumulation than others. Also, C. gariepinus is a generally omnivorous, had the least metals accumulation regardless of its habitat. Therefore, metal accumulation could be related to fish feeding habits. This confirms the report of Wiener and Giesy (1979) as well as Cross et al. (1973).

Several endemic fish species have become threatened (Nwani et al., 2010) leading to the depletion of our fish resources and substantial reduction in their nutritive values (Srivastava and Srivastava, 2008). Chemical analysis of fish, therefore, ensures dietary safety of the fish from a particular body of water (NOAA, 1988; Raoux et al., 1999). Also in a study (Jaji et. al., 2007) on the quality of Ogun River, lead and cadmium concentrations were found to be above the WHO limit.

\section{Conclusion}

In view of the importance of fish to diet of man, it is necessary that biological monitoring of the water and fish meant for consumption should be done regularly to ensure continuous safety of the seafood. Safe disposal of domestic sewage and industrial effluents should be practiced and where possible, recycled to avoid these metals and other contaminants from going into the environment. Laws enacted to protect our environment should be enforced. The activities at the upper-course of the Ogun estuary should be kept under strict surveillance as they are capable of increasing the heavy metals discharge into the river, especially as population is bound to increase. The values reported in this study could serve as baseline data to monitor future anthropogenic activities along the coast, now that a Liquefied Natural Gas Terminal and oil refineries are to be located in the area. The study showed a need for continuous pollution assessment study of aquatic organisms in Nigeria.

\section{References}

Adebisi, A. A. (1981). The physico-chemical hydrology of tropical seasonal river-upper Ogun River. Hydrobiologia, 79, 157-165. http://dx.doi.org/10.1007/BF00006123

Ademoroti, C. M. A. (1996). Environmental Chemistry and Toxicology (pp.171-204). Ibadan, Foludex Press Ltd..

Adeyeye, E. I., Akinyugha, R. J., Febosi, M. E., \& Tenabe, V. O. (1996). Determination of some metals in 
Clarias gariepinus (Cuvier and Valenciemes), Cyprinus carpio (L) and Oreochromis niloticus (L) fishes in a polyculture fresh water pond and their environment. Aquacut., 47, 205-214. http://dx.doi.org/10.1016/S0044-8486(96)01376-2

Allen, P. (1995). Chronic Accumulation of Cadmium in the edible Tissues of Oreochromis aurus (Steindachner): Modification by Mercury and Lead. Arch. Environ. Contam. Toxicol., 29, 8-14. http://dx.doi.org/10.1007/BF00213079

Arabatzis, G. D., \& Kokkinakis, A. K. (2005). Typology of the lagoons of Northern Greece According to their Environmental characteristics and fisheries Production. ORIJ contents, 5(1), 114-118.

Ashraf, W. (2005). Accumulation of heavy metals in kidney and heart tissues of Epinephelus microdon fish from the Arabian Gulf. Environ Monit Assess., 101, 311. http://dx.doi.org/10.1007/s10661-005-0298-4

Bajc, Z., Gacnik, K. S., Jenci, V., \& Doganoc, D. Z. (2005). The Content of Cu, Zn and Mn in Slovenian freshwater fish. Slov. Vet. Res., 42, 15-21.

Barak, N., \& Mason, C. (1990). A Survey of Heavy Metal Levels in Eels (Anguilla anguilla) from Some Rivers in East Anglia, England-The Use of Eels as Pollution Indicators. Internationale Revue Der Gesamten Hydrobiologie, 75(6), 827-833. http://dx.doi.org/10.1002/iroh.19900750624

Buikema, A. L. (Jr), Niederlehner, B. R., \& Cairns, J. (Jr). (1982). Biological Monitoring: Part IV-Toxicity Testing. Water Res., 16, 239-262. http://dx.doi.org/10.1016/0043-1354(82)90188-9

Coughtrey, P. J., \& Thorne, M. C. (1983). Radionuclide Distribution and Transport in Terrestrial and Aquatic Ecosystems: a Critical Review of Data, 2, 191-217.

Cross, F. A., Hardy, L. H., Jones, N. Y., \& Barber, R. T. (1973). Relation between total body weight and concentration of $\mathrm{Mn}, \mathrm{Fe}, \mathrm{Zn}, \mathrm{Cu}$ and $\mathrm{Hg}$ in the blue fish (Pomatonus saltatrix) and a bathy dermersal fish (Antimora rostrata). J. fish Res. Bd. Can., 30, 1287-1291. http://dx.doi.org/10.1139/f73-208

Cusimano, R. F., Brakke, D. F., \& Chapman, G. A. (1986). Effects of pH on the Toxicity of Cadmium, Copper and Zinc to Steelhead trout (Salmo gairdneri). Can. J. Fish Aquat. Sci., 43, 1497-1503. http://dx.doi.org/10.1139/f86-187

Daka, E. R., Ekeh, C. A., \& Moslen, M. (2008). Cadmium and lead level in some fish species from Azuabie creek in the Bonny Estuary, Nigeria. African J. Biotech., 7, 63-64.

Doherty, V. F., Ogunkuade, O. O., \& Kanife, U. C. (2010). Biomarkers of Oxidative Stress and Heavy Metal Levels as Indicators of Environmental Pollution in Some Selected Fishes in Lagos, Nigeria. American-Eurasian J. Agric. \& Environ. Sci., 7(3), 359-365.

Edem, C. A., Osabor, V., Iniama, G., Etiuma, R., \& Eke, J. (2009). Distribution of Heavy Metals in Bones, Gills, Livers and Muscles of (Tilapia) Oreochromis niloticus from Henshaw Town Beach Market in Calabar Nigeria. Pak. J. Nutr., 8(8), 1209-1211. http://dx.doi.org/10.3923/pjn.2009.1209.1211

Eralagere, T. P., \& Bhadravathi, R. K. (2008). Heavy Metal Transport in a sewage fed Lake of Karnataka, India. Proceedings of Taal 2007. The 12th World Lake Conference. 347-354.

FAO. (1983). Compilation of legal limits for hazardous substances in fish and fishery products. FAO Fishery Circular, 464, 5-100.

Farombi, E. O., Adelowo, O. A., \& Ajimoko, Y. R. (2007). Biomarkers of oxidative stress and heavy metals levels as indicators of environmental pollution in African catfish (Clarias gariepinus) from Ogun River. Int. J. Environ. Res. Public Health, 4(2), 158-165. http://dx.doi.org/10.3390/ijerph2007040011

FEPA. (2003). Guideline and Standards for Environmental Pollution and Control in Nigeria. Nigeria, Federal Environmental Protection Agency.

Filazi, A., Baskaya, R., Kum, C., \& Hismiogullar, S. E. (2003). Metal concentration in tissues of the Black sea fish Mugil auratus from Sinop-Icliman, Turkey. Human Exp. Toxicol., 22, 85-87. http://dx.doi.org/10.1191/0960327103ht323oa

Goodwin, T. H., Young, A., Holmes, M., Old, G., Hewitt, N., Leeks, G., ... Smith, B. (2003). The Temporal and Spatial Variability of Sediment Transport and Yields within the Bradford Beck Catchment, West Yorkshire. Science of the Total Environment, 314, 475-494. http://dx.doi.org/10.1016/S0048-9697(03)00069-X

Gosselin, R. E., Smith, R. P., \& Hodge, H. C. (1984). Clinical Toxicology of Commercial Products. 5th ed. Baltimore: Williams and Wilkins, 3-78. 
Hayat, S., Javed, M., \& Razzaq, S. (2007). Growth Performance of Metal Stressed Major Carps viz. Catla Catla, Labeo Rohita and Cirrhina Mrigala Reared under Semi-Intensive Culture System. Pakistan Veterinary Journal, 27(1), 8-12.

Heath, A. G. (1987). Water Pollution and Physiology, p. 145. Boca Raton, CRC press Inc.

Idodo-Umeh, G. (2002). Pollutant assessments of Olomoro water bodies using Physical, Chemical and Biological indices. Ph.D Thesis (p. 485), University of Benin, Benin City, Nigeria.

Idowu, A. A., \& Ayoola, S. O. (2008). Fish Resources and Physico-Chemical Parameters of Lagoon In Ogun Waterside Local Government Area, Ogun State, Nigeria. Journal of Environmental Extension, 7, 56-62.

Ishaq, E. S., Rufus, S. A., \& Annune, P. A. (2011). Bioaccumulation of Heavy Metalsin Fish (Tilapia zilli and Clarias gariepinus) organs from River Benue, North-Central Nigeria. Pak. J. Anal. Environ. Chem., 12(1\&2), 25-31.

Jaji, M. O., Bamgbose, O., Odukoya, O. O., \& Arowolo, T. A. (2007). Water Quality Assessment of Ogun River, South West Nigeria. Environmental monitoring and assessment, 133(1-3), 473-482. http://dx.doi.org/10.1007/s10661-006-9602-1

Kappus, H. (1987). Oxidative stress in chemical toxicity. Arch Toxicol., 60, 144-9. http://dx.doi.org/10.1007/BF00296968

Karthikeyan, S., Palaniappan, P. L. R. M., \& Sabhanayakan, S. (2007). Influence of pH and water hardness upon Nickel accumulation in edible fish Cirrhinus mrigala. J. Environ. Biol., 28, 484-492.

Kersten, M., \& Forstner, U. (1987). Cadmium in the Aquatic Environment (pp. 51-88), Nriagu JO and Sprague JB, ed. NY: Wiley.

Kime, D. E., Ebrahimi, M., Nysten, K., Roelants, I., Rurangwa, E., Moore, H. D. M., \& Ollevier, F. (1996). Use of computer assisted sperm analysis (CASA) for monitoring the effects of pollution on sperm quality of fish, application to the effects of heavymetals. Aquatic Toxicology, 36, 223-237. http://dx.doi.org/10.1016/S0166-445X(96)00806-5

Kucuksezgin, F. A., Kontas, O., Altay, E., \& Uluturhan, D. E. (2006). Assessment of marine pollution in Izmir Bay; Nutrient heavy metal and total hydrocarbon concentrations. Environ. Int., 32, 41-51. http://dx.doi.org/10.1016/j.envint.2005.04.007

Kurland, L. T., Faro, S. W., \& Siedler, H. (1960). Minamata Disease: The outbreak of a neurological disorder in Minamata, Japan and its relation to ingestion of sea food containing mercury compounds. World Neurol., 1 , 370-395.

Labonne, M., Basin, S., Othman, D., \& Luck, J. (2001). Lead Isotopes in Muscels as Tracers of Metal Sources and Water Movements in a Lagoon (Thau Basin, S. France). Chemical Geology, 181, (1-4), 181-191. http://dx.doi.org/10.1016/S0009-2541(01)00281-9

Mansour, S., \& Sidky, M. (2002). Ecotoxicological Studies. 3. Heavy Metals Contaminating Water and Fish from Fayoum Governorate, Egypt. Food Chemistry, 78(1), 15-22. http://dx.doi.org/10.1016/S0308-8146(01)00197-2

McCracken, I. R. (1987). Cadmium in the Aquatic Environment (pp. 89-116), Nriagu JO and Sprague JB, ed. NY: Wiley.

NOAA. (1988). A summary of selected data on chemical contaminants collected during 1984, 1985, 1986 and 1987. Washinton, DC; National Oceanic and Atmospheric Administration.

Novozamsky, I., Houba, V. J. G., van Eck, R., \& Vark, W. (1983). A novel digestion technique for multi-element plant analysis. Communications in Soil Science and Plant Analysis, 14, 239-248. http://dx.doi.org/10.1080/00103628309367359

Nwani, C. D., Nwachi, D. A., Ogokwu, O. I., Ude, E. F., \& Odoh, G. E. (2010). Heavy metals in fish species from lotic freshwater ecosystem at Afikpo, Nigeria. J. Environ. Biol., 31(5), 595-601.

Obasohan, E. E. (2007). Heavy Metals Concentrations in the offal, gill, muscle and liver of a freshwater mudfish (Parachana obscura) from Ogba River, Benin City, Nigeria. Afr. Journ. Biotech., 6(22), 2620-2627.

Obasohan, E. E., Oronsaye, J. A. O., \& Obano, E. E. (2006). Heavy Metal Concentrations in Malapterurus electricus and Chrysichthys nigrodigitatus from Ogba River in Benin City, Nigeria. Afr. Journ. Biotech., 5(10), 974-982. 
Odoemelan, S. A. (2005). J. Chem. Soc. Nigeria, 30(18).

Okoye, B. C. O., Afolabi, O. A., \& Ajao, E. A. (1991). Heavy Metals in the Lagos Lagoon Sediments. Int. J. Environ. Stud., 37, 35-41. http://dx.doi.org/10.1080/00207239108710615

Olaifa, F. G., Olaifa, A. K., \& Onwude, T. E. (2004). Lethal and Sublethal Effects of Copper to the African Catfish (Clarias gariepinus). African J. Biomed. Research, 7, 65-70.

Olaoye, O. J., Idowu, A. A., Omoyinmi, G. A. K., Akintayo, I. A., Odebiyi, O. C., \& Fasina, A. O., (2012). Socio-Economic Analysis of Artisanal Fisher Folks in Ogun Water-Side Local Government Areas of Ogun State, Nigeria. Global Journal of Science Frontier Research Agriculture \& Biology, 12(4), Version 1.0, 9-22.

Oronsaye, J. A. O., Wangboye, O. M., \& Oguzie, F. A. (2010). Trace Metals in Some Benthic Fishes of the Ikpoba River Dam, Benin City, Nigeria. Afr. Journ. Biotech., 9(51), 8860-8864.

Osman, A., Wuertz, S., Mekkawy, I., Exner, H., \& Kirschbaum, F. (2007). Lead Induced Malformations in Embryos of the African Catfish Clarias Gariepinus (Burchell, 1822). Environmental Toxicology, 22(4), 375-389. http://dx.doi.org/10.1002/tox.20272

Raoux, C., Bayona, J. M., Miguel, J. C., Teyssie, J. L., Fowler, S. W., \& Albauges, J. (1999). Particulate fluxes of alphatic and aromatic hydrocarbons in near-shore waters to the north-western Mediterranean Sea and the effect of continental runoff. Estuary Coast Shelf Sci., 48, 605-616. http://dx.doi.org/10.1006/ecss.1998.0458

Romeo, M., Siau, Z., Sidoumou, Y., \& Gnassia, M. B. (1999). Heavy Metal Distribution in Different Fish Species from the Mauritania Coast. Science of the Total Environment, 232(3), 169-175. http://dx.doi.org/10.1016/S0048-9697(99)00099-6

Shimuzu, Y. (1972). The Itai-Itai disease in polluted Japan. (Edited by Jun. U) J. Shukora Tokyo.

Shukla, V., Dhankhar, M., Prakash, J., \& Sastry, K.V. (2007). Bioaccumulation of Zn, Cu, and Cd in Channa puntatus. J. Environ. Biol., 28, 395-397.

Srivastava, R., \& Srivastava, N. (2008). Changes in nutritive value of fish Channa puntatus after chronic exposure to zinc. J. Environ. Biol., 29, 299-302.

UNEP. (1986). Assessment of the present state of pollution by cadmium, copper, zinc and lead in the Mediterranean Sea. Document UNEP/WG. 144/11 (Athen: UNEP).

Venugopal, B., \& Luckey, T. D. (1978). Metal Toxicity in Mammals, 2. New York: Plenum Press, 82.

Wiener, J. G., \& Giesy, J. P. (1979). Concentration of $\mathrm{Cd}, \mathrm{Cu}, \mathrm{Mn}, \mathrm{Pb}$ and $\mathrm{Zn}$ in fishes in a highly organic soft pond. J. Fish Res. Bd. Can., 36, 270-279. http://dx.doi.org/10.1139/f79-042

W. H. O. (World Health Organization). (1985). Guidelines for Drinking Water Quality (ii): Health Criteria and Supporting Information. Vol. 1, Recommendations. WHO, Geneva. pp. 130. 